\title{
"The Cultural Links between Galicia and Ireland Continue to Flourish Today": An Interview with the Director of the Irish Centre for Galician Studies (UCC) Martín Veiga
}

\author{
Verónica Membrive Pérez \\ University of Almería, Spain \\ veronicamembrive@hotmail.com
}

Copyright (c) 2017 by Verónica Membrive Pérez. This text may be archived and redistributed both in electronic form and in hard copy, provided that the author and journal are properly cited and no fee is charged for access.

\begin{abstract}
Dr. Martín Veiga Alonso is Director of the Irish Centre for Galician Studies and lecturer and co-ordinator of the Higher Diploma in Arts (Spanish) at the Department of Spanish, Portuguese and Latin American Studies at University College Cork. His main areas of research include contemporary Galician and Irish travel writing and poetry, with special focus on the Galician poet Antón Avilés de Taramancos, about whom he has published Escribir na multitude: a obra literaria de Antón Avilés de Taramancos (2014), Antón Avilés de Taramancos (2003), Biografía sonora de Avilés de Taramancos (2009), Cantos caucanos (2003) and the edited volume Raiceiras e vento. A obra poética de Antón Avilés de Taramancos (2003). Veiga is co-editor of Galicia 21: Journal of Contemporary Galician Studies and has recently edited a special issue devoted to the works of the Galician poet and essayist Xavier Queipo (2013). Furthermore, Martín Veiga is also a prolific translator and poet, and his volumes of poetry have received important awards. His collections are Tempo van de porcelana (1990), As últimas ruínas (1994, Espiral Maior Prize), Ollos de ámbar (2005, Esquío Prize) and Fundaxes (2006, Fiz Vergara Vilariño Prize). In this interview, held at University College Cork in July 2015, we discussed the historical vocation of Galician literature to look towards Ireland, as well as the role and activities of the Irish Centre for Galician Studies at UCC and the relevance and future of Galician Studies in Ireland and Europe.
\end{abstract}

Key Words. Galician Studies, Irish Centre for Galician Studies, Contemporary Irish Poetry, Contemporary Galician Poetry

Resumen. El Dr. Martín Veiga Alonso es un profesor gallego que actualmente dirige el Centro Irlandés de Estudios Gallegos en la Universidad de Cork (UCC). También ejerce su docencia en el Departamento de Español, Portugués y Estudios Latinoamericanos de la misma universidad, donde coordina el Diploma de Estudios Superiores (Spanish). Sus principales areas de investigación se centran en la literatura de viajes y en la poesía de Galicia e Irlanda, con especial atención a la obra del poeta gallego Antón Avilés de Tamarancos, sobre el que ha

ISSN 1699-311X 
publicado los libros Escribir na multitude: A obra literaria de Antón Avilés de Taramancos (2014), Antón Avilés de Taramancos (2003), Biografía sonora de Avilés de Taramancos (2009), Cantos caucanos (2003), así como la edición de Raiceiras e vento. A obra poética de Antón Avilés de Taramancos (2003). Veiga es coeditor de Galicia 21: Journal of Contemporary Galician Studies y ha editado recientemente un número especial dedicado a la obra del poeta y ensayista gallego Xavier Queipo (2013). Martín Veiga, además, es un prolífico traductor y poeta; sus volúmenes de poesía han obtenido importantes galardones: Tempo van de porcelana (1990), As últimas ruínas (1994, Premio Espiral Maior), Ollos de ámbar (2005, Premio Esquío) and Fundaxes (2006, Premio Fiz Vergara Vilariño). En esta entrevista, realizada en la Universidad de Cork en julio de 2015, tuve la oportunidad de discutir con el profesor Veiga sobre la vocación histórica de la literatura gallega hacía Irlanda y pude preguntarle por las actividades del Centro Irlandés de Estudios Gallegos en UCC, así como la relevancia y el futuro de los estudios gallegos en Irlanda y en Europa.

Palabras clave. Estudios gallegos, Centro Irlandés de Estudios Gallegos, poesía irlandesa contemporánea, poesía gallega contemporánea

\section{Verónica Membrive Pérez: Although there are other centres for Galician Studies around Europe and even in America, UCC has the only Irish Centre for Galician Studies. The Centre was created in 1998 by Professor David Mackenzie and you are currently the Director. Why did UCC decide to found the Centre?}

Martín Veiga: The appointment of David Mackenzie as Professor of Spanish at UCC in 1997 was obviously instrumental in this decision, as he was one of the great contributors to the international establishment of Galician Studies as an academic discipline, particularly in the English-speaking world. He had previously created a Galician Centre at the University of Birmingham, which unfortunately closed down only a few months ago, and replicated the model very successfully here in Ireland. After many years of involvement in the activities of the Centre as assistant director, I became director after David's retirement in 2008. Sadly, David passed away in February 2016 and he will be deeply missed both as a friend and as one of the key figures in the internationalisation of Galician Studies.

\section{VMP: Could you explain the main activities, objectives and future projects of the Centre since its foundation?}

MV: The Irish Centre for Galician Studies is a teaching and research hub that is intended to act as a platform of support to the development of Galician Studies in Ireland, particularly in the academic context of UCC, where it is anchored. It would be difficult to summarise all these years of activity in just a few lines. Some research theses on different Galician-related research topics have been completed at various postgraduate levels (MA, MRes and PhD), many research events have been organised in different areas ranging from sociolinguistics to film studies, from translation and creativity to theatre studies, and from poetry to new music discourses. The list of writers, artists, filmmakers and scholars who have read or spoken at events at the Centre throughout the years is remarkable and continues to increase. Many of these events have been organised in collaboration with other entities, a key aspect in the academic world today. We also value greatly the importance of undergraduate students, who have the opportunity to study Galician language and culture at UCC and who can also spend their year abroad studying in Galicia or even attend summer schools there thanks to the support of the Centre. 
VMP: There is a vocation of Galician literature to look towards Ireland; however, as Dennis O'Driscoll asserts, Irish intellectuals in their search for models to cope with an oppressive environment have on many occasions turned to writers from the former Eastern bloc (qtd. in Palacios and Lojo 2009: 14). Why do you think this has been the case?

MV: Different cultures look at different models to follow in order to find answers at times when their identity may be questioned and their freedom suppressed by more dominant forces. In relation to your question, scholars such as Stephanie Schwerter have studied the different sorts of interaction that modern and contemporary Irish poets, mostly from the North, have established with Russian literature. The Galician attraction for Ireland climaxed in the early 1920s, when Ireland was about to become an independent state and some intellectuals in Galicia also fostered similar political aspirations. The cultural links between Galicia and Ireland continue to flourish today in multiple forms, as the excellent work of Manuela Palacios aptly exemplifies.

VMP: Groups like Xeración Nós in the 1920s fed on different aspects of Irish culture and politics. Which distinctive features do you think most attracted Galician cultural movements like this one?

MV: In their attempts to establish a sense of Galician identity that was different from the Spanish (i.e. Castilian), the intellectuals of Nós projected an image of Galicia as an Atlantic Celtic nation and therefore opposed to the Mediterranean heritage that they associated with Spain. For Galicia, Ireland was an obvious cultural and political model as they were also fighting for independence from the British colonial power. Interestingly, this attraction was not limited to Galicia but was also experienced by other nations that shared similar expectations at the time, such as Catalonia. It is well known that the Xeración Nós carried out several initiatives in which this interaction with Irish referents became apparent, such as the publication in 1921 of a special issue of the journal Nós fully devoted to Ireland as a tribute to Terence MacSwiney, Lord Mayor of Cork, who had died after a hunger strike in 1920; the publication of Ramón Otero Pedrayo's partial translation of James Joyce's Ulysses in 1926 and the translations of two plays by W. B. Yeats published in 1935 by the Vilar Ponte brothers and Plácido Castro, also in the same journal.

VMP: The Francoist repression had a strong impact on Galician culture, since the regime silenced any public expression in Galician language and persecuted any democratic manifestation that supposed a threat towards the political and linguistic unity of Spain. Many intellectuals went into exile; however, authors continued writing. Which was the influence of exiled intellectuals on the preservation of Galician culture and language during this period?

MV: The influence of the exiled intellectuals was crucial in keeping the flame of Galician language and culture burning during the long period of the Francoist repression, which in Galicia was more cruel and intense than is often related. And indeed this flame burned very brightly, mostly in Buenos Aires, a city that came to be considered as the fifth province of Galicia and its cultural and spiritual capital during these times. Many publishing houses were created there, theatrical activity was carried out and many artists managed to express themselves as part of an open and vibrant community (naturally not without its tensions, but that would be another story). Another aspect that was important in this context was the 
fruitful, if rather complex, coexistence of the vital and cultural projects of Galician emigrants, many of whom had been in America for some time, such as Luís Seoane and Eduardo Blanco Amor, and the victims of exile after 1936.

VMP: You have thoroughly studied the life and works of the poet Antón Avilés de Taramancos. In Raiceiras $e$ vento (2003) you include the response of six Irish poets to Avilés de Taramancos's writing, which promotes the establishment of a fertile cultural dialogue between Ireland and Galicia. Could you talk about the Irish reception of the poetry of Avilés de Taramancos?

MV: His poetry has been translated only partially into English and this limitation has affected his reception in Ireland. However, the response of the Irish poets who contributed to the project was enthusiastic and some of the poems they created in dialogue with the poetry of Avilés were excellent. Some of those writers, such as Desmond O'Grady and Gregory O'Donoghue, have since passed away, which retrospectively gives the material a more poignant quality. In my experience, Irish writers are generally very open to working in collaboration with writers and translators from other cultures, so the possibility of generating intercultural interactions is quite frequent and often fertile, as you point out in your question.

VMP: You have also researched on Irish poet Pearse Hutchinson. His poetic development was influenced by his years in Spain and Portugal and he became a solid supporter of the Galician and Catalan languages. You say that the "continuity and intensity of [Hutchinson's] contacts with the Iberian world influenced his notions of identity" (2011: 136). In which ways?

MV: In many ways. I would say that his personal identity and his literary projects - in particular the poetry and the translations - were shaped by his experience of cultural and linguistic plurality in the Iberian context. I think that Hutchinson's awareness of the value of minority cultures, which he acquired initially in Spain, also contributed to reconfiguring his understanding of his own Irish language and culture. We must remember that he was a bilingual poet, who wrote both in English and in Irish, and a very active translator into both languages from many different European languages, mainly from Galician and Catalan. Before Hutchinson died in 2012, he donated his collection of Galician books to the Irish Centre for Galician Studies, where it is presently located (the rest of his books are in Maynooth). I am glad to report that the Hutchinson Galician collection will soon become one of the special collections in the Boole Library here at UCC, thus making this material available to all researchers.

VMP: Along these lines, most Irish authors write in English instead of Irish, a fact that does not alter their sense of Irishness. Which role do you think Galician language plays in relation to identity? Do you consider that the Galician writer's sense of identity may be affected by the usage of the Galician or the Spanish language?

MV: From a sociolinguistic point of view, the situation in Ireland is obviously very different but it is an interesting analogy. Identity in Galicia is inextricably linked to the use of the Galician language, viewed as a manifestation of our way of being in the world and interpreting reality through words. Therefore, the link between language and identity is crucial for Galician writers in the vernacular, because, through the mediation of this relationship, our work is situated in a very rich literary tradition which is defined by the use of the Galician language since the Middle Ages. I guess that Galician writers in the Spanish 
language, who generally play a minor role in the Galician literary field today, have to negotiate their own sense of belonging. In other words, they probably have to identify a way to position themselves and their work in relation to the continuity of the extraordinary legacy of Galician culture produced in the Galician language for centuries.

VMP: In relation to the use of vernacular languages, both Irish and Galician are progressively losing ground as a result of the prevalence of the other two more powerful languages, Spanish and English (Palacios and Lojo 2009: 17). The Galician sociolinguist Henrique Monteagudo, in a report on the sociolinguistic evolution in Galicia (19922003), confirms a decrease of monolingual speakers of Galician due to a lack of institutional support (2005: 94). Do you think that the decline of speakers of these two languages indicates that the linguistic policy in both countries has failed?

MV: Yes, I think that language policies in both countries have been inadequate and have failed to resolve the increasing decline in language users, particularly among the younger generations of speakers in urban environments. They have also failed to imaginatively address the diglossic status of both minority languages in their respective contexts. In Galicia, there is a tendency for young speakers to return to the use of the Galician language later in life, after years primarily speaking Castilian as their first option. Once again, the situation in this regard is extremely different in both Ireland and Galicia but there are also striking parallels. In order to transform this dynamic, we would need governments that show a commitment to the defence of their own languages and the national and international promotion of culture produced in those languages. In conclusion, they must bring to the fore the issue of language as a social and cultural priority to enable the citizens to engage more closely with their own living heritage.

VMP: Ireland frequently emerges in your poetry (e.g. "Elexía en inverno", 2003; "A Rosa", 1990, etc.). To which extent do you think Ireland influences your poetic production?

MV: I began reading Irish poetry towards the end of the 1980s, around the time in which I also started to write my own poems. I was immediately fascinated by the work of a very diverse range of authors such as W. B. Yeats, James Joyce, Brendan Behan and Seamus Heaney. I discovered other Irish writers a little later but, during those important formative years, Irish poetry played a crucial role in my development as a poet, particularly the work of Yeats and Heaney. I obviously continue to read them today, together with work by many contemporary poets. I think that the quality of Irish poetry today is excellent. So, to answer your question, some Irish poetry was an early influence and continues to be so. My life in Ireland has also generated an important source of experiences that have become important for my writing. On this note, I am glad to let you know that I have just published a new poetry collection in Galician, entitled Diario de Crosses Green, in which Ireland is the true protagonist. The book establishes a dialogue between my own cultural background and my perceptions of Cork as an urban space with the river Lee as a fundamental city presence.

VMP: The journal Galicia 21: Journal of Contemporary Galician Studies, created in 2007 and now jointly edited by Bangor University and UCC, aims to publish innovative research on relevant aspects of contemporary Galician culture. Where do you think Galician Studies is going? What is the present and future of Galician Studies? 
MV: It is great to be involved in Galicia 21. As you know, I am the current editor, together with David Miranda-Barreiro from Bangor, and we are about to publish our first issue (Issue F), which is looking great. The previous editors have done fabulous work establishing the journal as one of the key publications in the field and David and I are very excited with the prospect of continuing this activity and bringing the journal to new places in the near future. Galician Studies as an academic discipline has grown enormously and has achieved international recognition in recent years thanks to the sustained work and dedication of many academics all over the world, with special emphasis on developments in the US, the UK and Ireland. As examples of this recognition, the MLA has recently approved a Galician Language, Literature and Culture Forum as a permanent fixture of their convention, and the annual conference of the Association of Hispanists of Great Britain and Ireland (AHGBI) has hosted a Galician Studies panel for more than eleven consecutive years. I am the current convenor of this panel. These are very positive initiatives and I am of course delighted to be involved in some of them. However, there are also causes for concern for Galician Studies in the context of a more general crisis related to the way in which the humanities are perceived, at least in many European universities. This crisis has affected Galician as well as other minority languages and indeed many other areas in the humanities. The case of Galician at the University of Birmingham is a clear example. Hopefully this trend will reverse, common sense will prevail and we will start to grow again, because there are many young researchers in Galician Studies out there doing fantastic research who will eventually claim their chance to develop and consolidate their own professional careers. The future belongs to them but it is our responsibility to create strong foundations for these opportunities to materialise.

\section{VMP: Tell us about your latest poetry collection.}

MV: Diario de Crosses Green is my first poetry collection in ten years (the previous one was Fundaxes, published in 2006) and it is greatly indebted to my life in Ireland, my involvement in Irish life and my engagement with Irish culture, particularly through poetry. The book is a meditation on time and place. It has an unusual structural design, in that it features a poetic diary that traces the transformations perceived in the urban landscape more specifically in the area of Crosses Green, where I used to live in Cork city centre and where the river bends quite dramatically surrounding bridges and arches, an old brewery, traditional boat-making workshops - and registers the emotional responses that those changes stimulate in my own imagination. Each season invites a particular tone and different imagery. Every entry of this diary is followed by poems that respond to the spirit of the seasons and expand some of the observations and findings from the diary. Thus the book is an attempt to apprehend a particular time and a very specific place through the mediation of language. The collection was launched in Galicia (Noia and Santiago de Compostela) and it has been very well received so far, with several book reviews in journals, newspapers and digital media. I have also offered some readings, both in Galicia and in Ireland. Because Irish landscape both natural and emotional - is at the heart of Diario de Crosses Green, it is my intention to bring this book back to Ireland. In this regard, an English translation is being negotiated at the moment and I hope to see it published in the near future.

\section{Notes}

The research for this interview was supported by the project CEI Patrimonio, University of Almería. 


\section{Works Cited}

Monteagudo, Henrique. 2005. A Sociedade Galega e o Idioma. A Evolución Sociolingüística de Galicia (1992-2003). Galicia: Consello da Cultura Galega.

Palacios, Manuela, and Laura Lojo. 2009. "Poetry, Gender and Transnational Bonds: An Introduction." Writing Bonds: Irish and Galician Contemporary Women Poets. Eds. Manuela Palacios and Laura Lojo. Bern: Peter Lang. 13-30.

Veiga Alonso, Martín. 2003. Raceiras e Vento: a Obra Poética de Antón Avilés de Taramancos. Santiago de Compostela: Edicións Laiovento.

2011. "Travelling South: Representations of Iberia in the Poetry of Pearse Hutchinson". Reading Pearse Hutchinson: 'From Findrum to Fisterra'. Eds. Philip Coleman and Maria Johnston. Dublin: Irish Academic Press. 135-148.

Received: 12 May 2016 Revised version accepted: 28 November 2016

Verónica Membrive Pérez earned her Master's Degree in English Studies at the University of Almeria in 2011 and is currently writing her Ph.D. dissertation on Irish travel writers in Spain during the twentieth-century. She has delivered papers on Walter Starkie and his travels in Spain. Her field of research is Irish Literature, with a special focus on the relationships between Ireland and Spain. Her latest publication is "Walter Starkie and the Easter Rising: Facing History with Humour" in the collective volume Words of Crisis, Crisis of Words (2016). 